\title{
AUTOBIOGRAPHY AND SPACE: SLAVE NARRATIVES OF HARRIET JACOBS AND MARY PRINCE
}

\author{
Dr.Anshu Surve \\ Ms. Anwesha Basu
}

\begin{abstract}
The women writers in the 19th century represented themselves in the form of writings and presented their ideas through the medium of autobiography, a genre in the literary world. Genre, as per Collins dictionary, is 'a particular type of literature, painting, music, film or other art form which people consider as a class because it has special characteristics'. Autobiography is a tool to represent the 'Self' and during the 19th century, the women used it as one of her weapons to challenge the patriarchal and dominant upper class, wherein they were categorised in the marginalized section in terms of their origin and in creative writing field. Their writings became an agency or rather a space- emotional space within the cultural and societal space, where they put forth their emotions, desire to become emancipated, create a bench mark alongside other male writers in the literary world and inspire other women. This research paper attempts to explore autobiography in a new light through spatial theory as proposed by Henri Lefebvre and Edward Soja, vis-à-vis place and will posit the narratives which portrays the injustice done upon the marginalized people during the $19^{\text {th }}$ century. Space will act as a conceptual tool to narrate the slave narratives Incidents in the Life of a Slave Girl written by herself (1861) and The History of Mary Prince, a West Indian Slave. Related by Herself (1831) of Harriet Jacobs, an Afro-American slave in America and Mary Prince, a West Indian Slave in England respectively.
\end{abstract}


Towards Excellence: An Indexed, Refereed \& Peer Reviewed Journal of Higher Education / Mr. Anshu Surve \& Ms. Anwesha Basu / Page 33-41

Keywords: Autobiography, female writers, slave narrative, space Autobiographies . . . may reveal as much about the author's assumed audience as they do about him or her, and this is a further reason why they need to be read as cultural documents, not just as personal ones.

- Robert F. Sayre, American Lives: An Anthology of Autobiographical

\section{Writing}

Autobiography is awfully seductive; it's wonderful. Once I got into it, I realized I was following a tradition established by Frederick Douglass - the slave narrative - speaking in the first-person singular, talking about the first-person plural, always saying 'I,' meaning 'we.'

- Maya

Angelou

The word 'Autobiography' has been borrowed from the Greek words- 'autos' meaning self, 'bios' meaning life and 'graphe' meaning write. Stephen Spender, a British critic defines autobiography as "the story of one's life written by himself." Robert Southey is credited to have coined the term but in 1797, the word was made-up by a linguist for the sake of having a common term in order to bridge the gap of different accounts that the authors narrated in their narratives.

The first wave of feminism began in the $19^{\text {th }}$ century in England. Mary Wollstonecraft's work Vindication of the Rights of Women, 1792 and John Stuart's workThe Subjection of Women, 1869 empowered other women to fight against the imbalance of gender existing within the society. They fought against the society for the rights of the women; their works acted as a catalyst for the women which encouraged them to speak up for themselves and their rights. Even in America, there were movements carried out by women like the suffrage movement, a part of feminism; fighting against the patriarchal 
Towards Excellence: An Indexed, Refereed \& Peer Reviewed Journal of Higher Education / Mr. Anshu Surve \& Ms. Anwesha Basu / Page 33-41

society and similar related events in the course of history.There were women writers who challengedthe literary society comprised of white male, the one with the power, who dictated the rules and regulations of the society in general.

Harriet Jacobs makes use of the pseudonym Linda Brent to hide her identity and to avoid being attacked the men of the literary society. Her work, Incidents in the life of a Slave Girl, Written by Herself, 1861, is a fitting example of autobiography as a social discourse. She uses a sentimental tone to invoke pain and the need to unite as one, that is white and black women being together to raise their voices against the injustices and the need to remove the tag of 'marginalized' from them. Harriet Jacobs through her autobiography primarily discusses about her sexual harassment, her constant fight to free herself and moving towards the North and finally freeing herself. She narrates at the end that she doesn't really feel free even after running away as she lives within the patriarchal racist society. She lays emphasis on her resentment towards the cultural, social, economic and political imbalance which is another reason why she did not feel emancipated. This work targeted the female of America to feel powerful and unite to fight against the patriarchy and the injustices that existed in their day to day life.

Mary Prince was a former black women slave in England whose narrative work The History of Mary Prince, a West Indian Slave. Related by Herself,1831 focused on slavery and the injustices tied to it. She was the first black female writer in England whose work was published. Her slave narrative talked about the cruelty that a slave has to endure, anti- slavery, the impact that slavery had upon their personal lives and the humiliation faced by the female slaves. She was one of the key members who assisted in the abrogationof slavery in England. Her autobiography became a voice, a tool which helped the readers realize the barbarous and inhuman treatment given to the slaves, especially the black female slaves. 
Towards Excellence: An Indexed, Refereed \& Peer Reviewed Journal of Higher Education / Mr. Anshu Surve \& Ms. Anwesha Basu / Page 33-41

As per RoutledgeEncyclopedia of Philosophy, Space is "meant to stand for a boundless extension which supposedly contains everything or everything of a certain sort [..] it does not refer to anything that can be exhibited in sense perception". Henri Lefebvre's popular work The Production of Space, analyses space with respect to the social context. He takes up a Marxist approach and connects space with 'capital and capitalism'. For understanding the concept of 'space', it becomes essential for one to understand the concept of region and place in depth. Region is a geographical concept, but with transition, that particular region becomes a social science concept and as we go on to critically analyse that explicitly, we come across the political, social and cultural contexts with that region. A place is embodied within region. A region consists of geographical space, social space, emotional space and psychological space. The emotional space consists of the feelings of the 'Self' while the psychological space describes the thinking process affected by the geographical locations, societal and cultural norms. Emotional and psychological space is manifested within the literary space, a space where the literary writings exists.

Henri Lefebvre asserts social space being a social product. It can be correlated with capital and capitalism where there are three inter related levels such as biological reproduction/family, the production of labour and the reproduction of social relationsrelated to production. Thereby, the social space metamorphosizes into a space for the person who modifies oneself according to the society which is directly affected by the capitalist and bourgeoisie class and their rules. Social space is directly and indirectly produced and reproduced in connection with the forces of production. When we delve into social space, we can understand how the social space is an amalgamation of cultural, topological and Marxist space. This space does not ignore the 'locals', which means they do not ignore the marginalized section of the society as they are also the part of the society. Harriet Jacobs and Mary Prince belonged from the marginalized section, but their writings became the part of the social space. They exposed the reality of the society of how they were treated just because they were 
Towards Excellence: An Indexed, Refereed \& Peer Reviewed Journal of Higher Education / Mr. Anshu Surve \& Ms. Anwesha Basu / Page 33-41

powerless by the power men and encouraged other women writers of the society to put forth their opinions and feelings through the medium of writing.

Culture consists of social behaviour and norms that exists within the society. A culture can be described as the code of conduct which the people living in that society follows. Cultural space, a space which follows the guidelines constructed by the society of a particular place; which have significant meanings of its society. In the words of Martin and Nakayama, the cultural space can be physical and metaphorical. Culture influences the mind-set of the people, thereby dictating them to live the rules and regulations. Culture also involves religion practices, social networking, social networking which affects the identity of a person.

Emotional space falls under the category of psychological space. 'Emotions', according to Oxford dictionary, means 'strong feelings such as love, fear or anger'. Emotional space thereby, means a space where different feelings exists. This space is a place where a person can independently express their feelings towards or against any agency of the society. Emotional space is directly related with the cultural, economic and political condition of the society. This effects the person to the extent that sometimes people express their opinions in the form of writings and protests. Emotional space is directly related with the cultural, economic and political conditions of the society. These affects the person to the person to the extent that sometimes people express their opinions in the form of writings and protests. Harriet Jacobs and Mary Prince, both choose writing as a weapon to express their emotional upheaval. Their writings reveal the societal the societal conditions of the $19^{\text {th }}$ century and women were treated not only in the society but also in the literary world.

For Heidegger, "language is the house of being" meaning humans exist due to the usage of language in their day to day lives for communication. Language becomes an agent for their thoughts, it becomes their space which reflects where they belong from 
Towards Excellence: An Indexed, Refereed \& Peer Reviewed Journal of Higher Education / Mr. Anshu Surve \& Ms. Anwesha Basu / Page 33-41

and their thoughts about that particular place. Similarly, for Harriet Jacobs and Mary Prince, their autobiography became a space where they exhibited their thoughts and portrayed their life out in the form of writings.

Place plays an important role in space as it makes an identity of a person. Their cultural and social norms makes/structures a person's thoughts and experiences. According to Henri Lefebvre and Edward Soja, physical and social space is directly related with everyday life. A place gives a meaning to one's own identity which can be regional identity, collective identity or individual identity. Therefore, we can say, place is made up of cultural and social norms of that particular society. A place thereby becomes a reflection, introspection and self-understanding for a person.Place is semiotically manifested space, while space is physically and socially constructed (Knox and Marston, 2001).

Place made a huge impact on the lives of these two women. Their identity was established due to this place, an identity of a black women; which made them feel suffocated within the white male dominated society. Their identity was projected in their autographical narrative which explicitly discussed the scenario of their society and tried to empower women and represented themselves as 'Self' in the society.

The writings of a person as we know are influenced to an extent by the social and cultural aspects of the community. Autobiography, a genre in the literary writing field consumes the social and cultural space. It depicts the author's feelings and reactions towards a particular society, his/her own experiences within the society etc. Harriet Jacobs and Mary Prince's autobiographies paint the emotions they had felt within the American and British society; their work became an instrument for the women to feel emancipated and motivate other women in the society to resist and fight for their rights. Their autobiographies become a space in itself within the cultural and social space. 
Towards Excellence: An Indexed, Refereed \& Peer Reviewed Journal of Higher Education / Mr. Anshu Surve \& Ms. Anwesha Basu / Page 33-41

Harriet Jacobs and Mary Prince through their autobiographies, narrative space verbalized their confinement of their respective societies in the $19^{\text {th }}$ century America and England. The narrative is a social product, a tool which gave them a voice and feel emancipated. Autobiography, thus can be seen as a tool which allowed the establishment of the Self apart from attacking the social, cultural and literary norms that existed in the $19^{\text {th }}$ century and to inspire other women to resist and raise their voices against them who gave them the 'marginalized' tag, for being 'Black' and for being a 'Female'. Though Harriet Jacobs and Mary Prince were from different places, they shared the same goals and thoughts, that is to make the women of their society feel emancipated and fight for equality. Thus, autobiography for both the female writers became a space for their raising their voices and pass on the message to the other women, along with narrating their emotions regarding the society. 
Towards Excellence: An Indexed, Refereed \& Peer Reviewed Journal of Higher Education / Mr. Anshu Surve \& Ms. Anwesha Basu / Page 33-41

\section{Works Cited}

Berryman, Charles. "Critical Mirrors: Theories of Autobiography." Mosaic (Winnipeg), vol. 32, no. 1, 1 Mar. 1999, p. 71, www.questia.com/library/journal/1G154482283/critical-mirrors-theories-of-autobiography.

Casmier-Paz, Lynn A. "Footprints of the Fugitive: Slave Narrative Discourse and the Trace of Autobiography." Biography, vol. 24, no. 1, 2001, pp. 215-225, 10.1353/bio.2001.0002. Accessed 3 Feb. 2020.

Discourse: The Example of Harriet Ann Jacobs." College English, vol. 66, no. 2, Nov. 2003, p. 133, 10.2307/3594263. Accessed 4 Feb. 2020.

Doriani, Beth Maclay. "Black Womanhood in Nineteenth-Century America: Subversion and Self-Construction in Two Women's Autobiographies." American Quarterly, vol. 43, no. 2, June 1991, p. 199, 10.2307/2712924. Accessed 9 Feb. 2020.

"Incidents in the Life of Harriet Jacobs." Www.Laphamsquarterly. Org, www.laphamsquarterly.org/harriet-jacobs/index.

Kiple, K. F., et al. "The History of Mary Prince: A West Indian Slave, Related by Herself." The International Journal of African Historical Studies, vol. 21, no. 4, 1988, p. 742, 10.2307/219775. Accessed 4 Feb. 2020.

Manfra, Meghan, et al. INCIDENTS IN THE LIFE OF A SLAVE GIRL.

Stover, Johnnie M. "Nineteenth-Century African American Women's Autobiography as Social

Tricomi, Albert H. "Dialect and Identity in Harriet Jacobs's Autobiography and Other Slave Narratives." Callaloo, vol. 29, no. 2, 2006, pp. 619-633, 10.1353/cal.2006.0125. Accessed 23 Feb. 2020.

Yellin, Jean Fagan. "Written by Herself: Harriet Jacobs' Slave Narrative." American Literature, vol. 53, no. 3, Nov. 1981, p. 479, 10.2307/2926234. Accessed 23 Feb. 2020. 


\section{Dr.Anshu Surve \\ Assistant Professor \\ Department of English \\ Faculty of Commerce}

The Maharaja Sayajirao University of Baroda,Vadodara.

Email: anshu.surve-eng@msubaroda.ac.in

\&

\section{Ms. Anwesha Basu \\ Research Scholar Department of English \\ Faculty of Arts}

The Maharaja Sayajirao University of Baroda, Vadodara

Email: anwesha2310@gmail.com 